\title{
Penerapan Algoritma K-Means Untuk Pendataan Obat Berdasarkan Laporan Bulanan Pada Dinas Kesehatan Kabupaten Lombok Timur
}

\author{
Suhartini1, Lalu kerta Wijaya2, Nur Arini Pratiwi ${ }^{3}$ \\ 1,2Program Studi Teknik Informatika, Universitas Hamzanwadi \\ 3Program Studi Sistem Informasi, Universitas Hamzanwadi \\ suhartini311279@gmail.com
}

\begin{abstract}
Abstrak
Obat merupakan salah satu komponen yag sangat penting dalam hal kesehatan baik untuk mencegah, mengurangi, menghilangkan atau menyembuhkan suatu penyakit maupun gejala penyakit.[1] Dengan dilakukannya pengolahan obat setiap bulannya dapat menjadi salah satu sumber pengambilan keputusan untuk menjamin ketersediaan obat yang lebih efektif dan efisien.[2] Akan tetapi pendataan obat pada dinas kesehatan yang bertempat di Kabupaten Lombok Timur mengalami berbagai kendala yang dihadapi diantaranya kesulitan dalam pengelompokan data obat yang berdampak pada pembengkakan penyimpanan obat yang mengakibatkan penyedian dan pendistribusian obat terhambat.[3] Oleh karena itu perlu adanya metode yang membantu sistem pengelompokan pendataan obat berdasarkan laporan bulanan. Metode K-Means diharapkan mampu mengelompokkan pendataan obat bulanan yang dapat dijadikan sebagai acuan perencanaan persediaan obat pada tahun berikutnya, selain itu informasi yang dihasilkan dari metode ini dapat digunakan sebagai rekomendasi pada puskesmas maupun rumah sakit untuk meningkatkan pelayanan kesehatan masyarakat.[1] Kriteria obat yang paling banyak di Dinas Kesehatan Kabupaten Lombok Timur adalah sebanyak 193 item. Hal ini disebabkan karena pemakainnya paling banyak dilihat dari pemakaian perbulan. Kelompok obat yang pemakaiannya lebih sedikit ada 2 irisan yaitu pertama obat dengan jumlah kelompok 4, item yang pemakaiannya lebih sedikit dari kelompok 1. Kedua yaitu obat dengan jumlah kelompok 3 , item yang pemakaiannya paling sedikit dari kelompok 1 dan kelomok 2.[2]
\end{abstract}

Kata kunci : $k$-means, obat, pendataan

\begin{abstract}
Medicine is one of the most important components in terms of health both to prevent reducing or cure a disease or symptoms of the disease bydoing medication processing every month can be a source decision making to ensure the availability of more effective and efficient drugs. However, the implementation of medicine for the health services district in lombok east has been affected by the difficulties dealt with with drug data documentation that resulted in increased drug use, and the distribution of drugs was hampered not only. Therefore there needs to be a method that helps the system of drug-filing systems based on monthly reports. Kmeans is expected to be able to group monthly medications that can be used as a model for planning medical supplies the following year, and the information generated from them can be used as a recommendation in both community centers and hospitals to improve public health services. The criteria for the most drugs in the East Lombok District Health Office were 193 items. This is because the usage is seen the most from monthly usage. There are 2 slices of drug use there are 2 slices, namely the first drug with group number 4 , the item is less use than group 1. Second, there are drugs with group 3 number, the item which has the least use of group 1 and group 2.
\end{abstract}

Keywords : K-Means, Drug, Record 


\section{Pendahuluan}

Peran tekhnologi informasi sangatlah penting dalam berbagai bidang terutama bidang kesehatan. Dimana kesehatan merupakan hak asasi manusia dan sekaligus merupakan investasi untuk keberhasilan pembangunan bangsa indonesia. Oleh karena itu perlu dilakukan pembangunan kesehatan secara menyeluruh dan berkesinambungan guna meningkatkan kesadaran atau kemampuan hidup sehat bagi setiap orang.[3] Salah satu caranya adalah dengan meningkatkan akses dan mutu pelayanan masyarakat.

Dinas Kesehatan Lombok Timur merupakan instansi kesehatan yang di dalamnya terdapat Gudanng Farmasi yang dijadikan sebagai tempat penyimpanan obat dan pusat pendistribusian obat ke berbagai puskesmas, rumah sakit, maupun apotek yang ada di Kabupaten Lombok Timur dimana setiap pemakaian obat perbulannya dilakukan pendataan sebagai acuan persediaan obat pada tahun berikutnya.

Obat merupakan salah satu komponen yang sangat penting dalam hal kesehatan baik untuk menyembuhkan maupun mengurangi rasa sakit dari penyakit yang di derita oleh setiap orang, tidak hanya itu pemakaian obat juga memeberikan kita informasi tentang apa saja penyakit yang diderita oleh setiap orang dimana informasi tersebut sangat membantu petugas kesehatan[4]. Untuk itu obat perlu dikelola dengan baik, dengan dilakukannya pendataan obat setiap bulannya yang kiranya mampu menjamin ketersediaan dan pemerataan obat dengan jenis dan jumlah yang mencukupi sehingga obat dapat diperoleh dengan cepat oleh rumah sakit, puskesmas, maupun apotek.[5] Hal tersebut membuktikan bahwa pendataan obat yang baik sangatlah berpengaruh terhadap penyimpanan, pendistribusian, dan pemakaian obat yang lebih efektif dan efisien di tempat pelayanan kesehatan. Akan tetapi jika pendataan obat tidak dibarengi dengan pengelompokan data obat yang baik, maka hal itulah yang dapat menimbulkan pembengkakan penyimpanan obat yang justru tidak dominan dipakai, hal inilah yang nantinya menghambat layanan kesehatan[6].

Pada Dinas Kesehatan Kabupaten Lombok Timur terdapat permasalahan yang ditemukan yaitu data pemakaian obat setiap bulannya masih dikelompokkan secara manual, sehingga petugas Gudang Farmasi Dinas Kesehatan hanya mengetahui jumlah pemakaian tanpa mengetahui karakteristik obat seperti apa yang sering dipakai sehingga pengadaan obat dilakukan secara random tidak sesuai dengan data pemakaian bulanan hal inilah yang menyebabkan pembengkakan penyimpanan obat yang berdampak pada ketidaklancaran pendistribusian obat. Oleh karena itu, peneliti akan mengimplementasikan data mining dalam mengelompokkan data obat dengan metode clustering dengan menggunakan algoritma $k$ means dimana metode ini dapat membantu dalam pengelompokan pemakaian obat dengan cara komputerisasi agar dapat diketahui secara mudah karakteristik obat seperti apa saja yang sering dipakai dan dapat dijadikan acuan 
pengadaan obat untuk tahun berikutnya, sehingga pengadaan obat yang tidak terlalu sering dipakai dapat diminimalisir guna mencegah pembengkakan penyimpanan obat.[1]

\section{Tinjauan pustaka}

\subsection{Penelitian Terkait}

Terdapat beberapa penelitian terkait dengan penggunaan data mining metode cluster dengan menggunakan Algoritma K-Means untuk dapat mengelompokkan data, diantaranya adalah :

- Penelitian oleh Cici Astria. Penelitian ini Membahas tentang metode k-means pada pengelompokan wilayah pendistribusian listrik. Sumber data penelitian ini dikumpulkan berdasarkan dokumendokumen keterangan energi yang dihasilkan oleh Direktorat Jenderal Bea dan Cukai. Data yang digunakan dalam penelitian ini adalah data dari tahun 2011-2017 yang terdiri dari 34 provinsi. Variable yang digunakan jumlah pendistribusian listrik berdasarkan wilayah. Metode yang digunakan untuk meyelesaikan kasus ini adalah memanfaatkan teknik datamining dengan metode k-means. Data diolah dengan bantuan software RapidMiner dan melakukan 2 cluster yaitu cluster tingkat distribusi tinggi (C1) dan cluster tingkat distribusi rendah (C2). [5]

- Penelitian oleh Dinda Nabila Batubara. Penelitian ini betujuan untuk mengelompokan daerah resapan air menggunakan algortima datamining dengan metode K-Means. Data yang digunakan dalam penelitian ini adalah data persentase rumah tangga berdasarkan provinsi dan keberadaan area resapan air pada tahun 2017 yang terdiri dari 34 provinsi di Indonesia. Berdasarkan data tersebut dieproleh pengelompokan area resapan air berdasarkan provinsi menjadi 2 clusteryaitu cluster tinggi (C1) dan clusterrendahmenggunakan K-means clustering. Dari hasil penelitian diperoleh pengelompokan menjadi 16 provinsi dengan cluster tinggi(C1) dan 18 provinsi dengan clusterrendah (C2). Hal ini dapat menjadi masukan pada pemerintah untuk provinsi yang memiliki daerah resapan air rendah menjadi perhatian lebih berdasarkan cluster yang telah dilakukan.[6]

- Penelitian oleh Mawaddah Anjelita.. Penelitian ini membahas tentang Analisis Metode K-Means pada Kasus Ekspor Barang Perhiasan dan Barang Berharga Berdasarkan Negara Tujuan Utama. Data diperoleh dari situs resmi pemerintahan yaitu Badan Pusat Statistik Indonesia yang dikelola oleh Direktorat Bea Cukai. Pada penelitian ini, peneliti menggunakan data tahun 2012-2017 yang terdiri dari 11 negara tujuan utama eksporperhiasan dan barang berhargayaitu Swiss, Singapura, Hongkong, Uni Emirat Arab, Afrika Selatan, Taiwan, Amerika Serikat, India,Australia, Italia, dan negara lainnya. Variabel yang digunakan ada 2, yang pertama jumlah ekspor berat 
bersih dan yang kedua nilaiFree On Board (FOB). Data tersebut dicluster menjadi 2, yaitu cluster ekspor tingkat tinggi(C1) dan cluster ekspor tingkat rendah(C2).[7]

- Penelitian oleh Muhammad Aliyul Amri. Penelitian ini membahas tentang penerapan datamining terkadap pengelompokan penerima imunisasi anak-anak menurut provinsi menggunakan metode $\mathrm{k}$ meansclustering. Sumber data penelitian ini dikumpulkan dari dokumen-dokumen tahun 2015-2018 dari Badan Pusat StatistikBPS Indonesia. Berdasarkan data tersebut diketahui 2 cluster yaitu cluster tingkat penerimaan imunisasi tinggi (C1) dan cluster tingkat penerimaan imunisasi rendah. Hasil penelitian diperoleh bahwa 19 provinsi berada di cluster tingkatpenerimaan imunisasi tinggi dan 15 provinsi berada di cluster tingkat penerimaan imunisasi rendah. [2]

- Penelitian oleh Deny Novianti. Berdasarkan data yang ada, tidak disebutkan negara mana sajakah yang termasuk dalam pendaftaran patennya yang tertinggi ataupun terendah. Sehingga tidak dapat diketahui Negara mana saja yang berpotensi paling banyak mendaftarkan paten untuk ke depannya. Data yang digunakan untuk dikelompokkan menggunakan metode K-Means Cluster Analysis adalah database KI dengan parameternya yaitu jenis Paten, yaitu paten dan paten sederhana yang ada dari tahun
2016 sampai dengan tahun 2018. Tahapan dalam menggunakan metode tersebut dimulai dari penentuan titik pusat awal, perhitungan jarak antar cluster dan menentukan besarnya rasio. Berdasarkan hasil penelitian ini, diperoleh hasil India dan Singapore adalah Negara tertinggi selama tiga tahun terakhir dalam pendaftaran paten di Indonesia.[8]

Penelitian oleh M.Hasmil Adiya. Clustering dalam data mining dapat digunakan untuk menganalisa pemakaian obat-obatan, perencanaan danpengendalian obat-obatan di rumah sakit. Metode yang akan di pakai untuk clustering data obatobatan dalah algoritma K-Means yang merupakan metode data clustering non hirarki yang mempartisi data ke dalam cluster sehingga data yang memiliki karakteristik yang samadikelompokkan ke dalam satu cluster yang sama dan data yang mempunyai karakteristik yangberbeda dikelompokkan ke dalam kelompok lain. Tujuan dari penelitian ini adalah untukmengelompokkan data obat-obatan di Rumah Sakit Umum Daerah Pekanbaru yang dapat digunakan sebagai referensi dalam pengambilan keputusan dalam perencanaan danpengendalian pasokan medis di rumah sakit tersebut.[1] 


\subsection{Landasan teori}

\section{Pengertian Penerapan}

Menurut kamus besar bahasa Indonesia (KBBI), pengertian penerapan adalah perbuatan menerapkan, sedangkan menurut beberapa ahli, penerapan adalah suatu perbuatan mempraktekkan suatu teori, metode, dan hal lain untuk mencapai tujuan tertentu dan untuk suatu kepentingan yang diinginkan oleh suatu kelompok atau golongan yang telah terencana atau tersusun sebelumnya.[9]

\section{Pengertian Data Mining}

Ada beberapa definisi data mining, secara umum data mining dapat didefinisikan sebagai berikut:

- Proses penemuan pola yang menarik dari data yang tersimpan dalam jumlah besar.

- Ekstraksi dari suatu informasi yang berguna untuk menarik (non-trival, implisit, sebelumnya belum diketahui, potensial kegunaannya) pola atau pengetahuan dari data yang disimpan dalam jumlah besar.

- Eksplorasi dari analisa secara otomatis atau semiotomatis terhadap data-data dalam jumlah besar untuk mencari pola dan aturan yang berarti.[10]

\section{Metode Clustering}

Clustering adalah salah satu teknik dari salah satu fungsionalitas data mining, algoritma cluster yang merupakan algoritma yang digunakan dalam pengelompokan sejumlah data ke dalam kelompok-kelompok data tertentu (cluster)[11]..

\section{Pengertian Algoritma K-Means}

Dari beberapa teknik klastering yang paling sederhana dan umum dikenal adalah clustering K-Means. Untuk melakukan klastering ini, nilai $\mathrm{k}$ harus ditentukan terlebih dahulu. Biasanya user atau pemakai sudah memilki informasi awal tentang objek yang sedang dipelajari, termasuk berapa jumlah klaster (cluster) yang paling tepat. Secara detail bisa menggunakan ukuran ketidakmiripan untuk mengelompokkan objek. Ketidakmiripan bisa diterjemahkan kedalam konsep jarak. Jika jarak dua objek atau data titik cukup dekat, maka dua objek itu mirip. Semakin dekat berarti semakin tinggi kemiripannya. Semakin tinggi nilai jarak, semakin tinggi ketidakmiripannya.[12]

\section{Pengertian Dataset}

Dataset adalah objek yang merepresentasikan data dan relasinya di memory. Strukturnya mirip dengan data yang ada di database. Dataset berisi koleksi dari data tabel dan data[11]. Jenis dataset ada dua macam yaitu :

1) Private Dataset

Private dataset yaitu dataset yang dapat diambil dari organisasi yang kita jadikan tempat atau objek penelitian. Adapun contoh-contohnya seperti instansi, rumah sakit, pabrik, perusahaan jasa, etc.

2) Public Dataset

Public dataset yaitu dataset yang dapat diambil dari repository public yang telah disepakati oleh para peneliti. Adapun contoh-contohnya seperti: UCI. [13] 


\section{Pengertian Rapidminer}

RapidMiner merupakan software/perangkat lunak untuk pengolahan data, dengan menggunakan prinsip dan algoritma data mining, RapidMiner mengekstrak pola-pola dari dataset yang besar dengan mengkombinasikan metode statistika, kecerdasan buatan dan database. [14]

\subsection{Tahapan penelitian}

Flowchart adalah penggambaran secara grafik dari langkah-langkah dan urut-urutan prosedur dari suatu programFlowchart biasanya mempermudah penyelesaian suatu masalah khususnya masalah yang perlu dipelajari dan dievaluasi lebih lanjut. Adapun alur flowchart dari metode klastering menggunakan algoritma K-Means adalah sebagai berikut :[6]

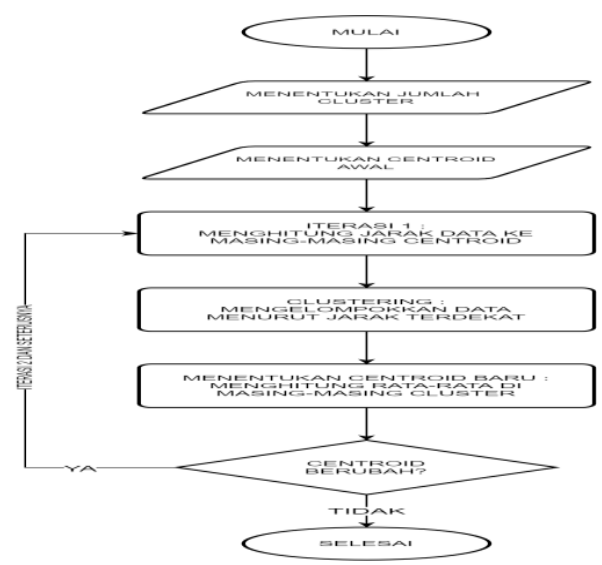

Gambar 1. Alur skema K-Means

Penjelasan:

- Menyiapkan data yang akan diolah

- Menentukan jumlah cluster

- Menentukan centroid awal secara acak (Random)

Melakukan perhitungan jarak data ke masingmasing centroid. Perhitungan ini menggunakan rumus jarak euclidean. Perhitungan pertama ini selanjutnya disebut iterasi 1 dan menghasilkan perhitungan nilai cluster.[10]

Setelah mengetahui nilai cluster, langkah selanjutnya adalah mengelompokkan data berdasarkan jarak terdekat dari titik centroid.[15] Langkah selanjutnya adalah menentukan centroid baru atau atau pusat baru menggunakan hasil dari setiap anggota pada masing-masing cluster, dengan cara mencari nilai rata-rata dari data. Nilai rata-rata inilah yang selanjutnya menjadi titik centroid baru. Jika tidak ditemukan lagi perubahan posisi pada data dan perubahan titik pusat centroid, maka proses selesai. Tapi jika posisi pada datanya berubah dan titik centroid berubah, maka akan dilakukan iterasi atau perulngan selanjutnya.[12]

\section{Metode Penelitian}

Adapun metode penelitian yang digunakan dalam penelitian ini adalah:

- Observasi

Dilakukan dengan mengumpulkan data dari penelitian secara langsung di Dinas Kesehatan Kabupaten Lombok Timur berdasarkan fakta dan kenyataan.

- Wawancara

Dilakukan dengan cara tanya jawab langsung dengan para petugas Gudang Farmasi mengenai data obat yang ada di Dinas Kesehatan Lombok Timur. 
- Studi pustaka

Digunakan untuk menambah refrensi terkait topik penelitian, yang didapat melalui bukubuku maupun internet.

\section{Hasil Dan Pembahasan}

Dibawah ini merupakan tahapan- tahapan dalam penelitian yang dilakukan:

1. Proses Pemilihan Operator

Disini peneliti menggunakan Read Excel dalam menampilkan operator view. Selanjutnya peneliti mengklik Import Configuration Wizard pada pojok sebelah kanan untuk ke tahap berikutnya, maka akan muncul tampilan seperti gambar 1 .

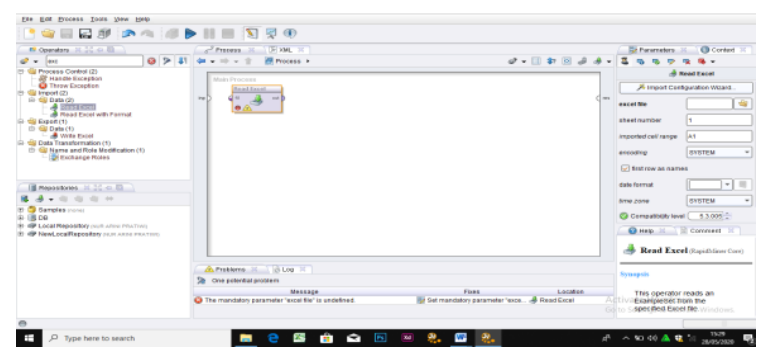

Gambar 1. Pemilihan Operator View

\section{Penginputan Dataset}

Selanjutnya pada tahap ini menjelaskan suatu penginputan dataset yang akan di proses pada RapidMiner5 lalu kemudian dicari dataset yang akan di clusteringkan untuk tahapan proses selanjutnya Seperti contohnya Read Excel yang digunakan harus sesuai dengan format data yang diinputkan.

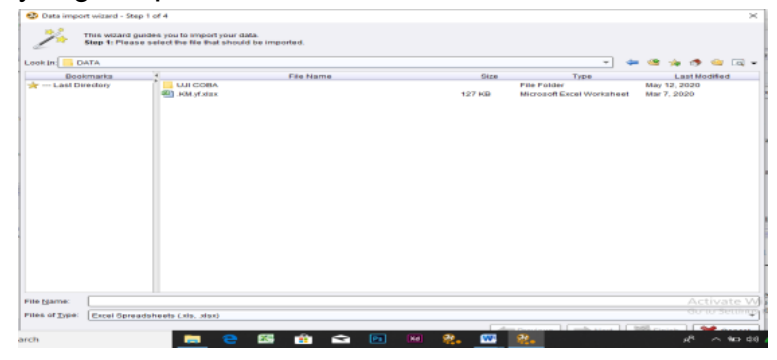

Gambar 2. Proses Penginputan Dataset
3. Pemilihan Data Yang Akan Menjadi Hasil

Pada tahap ini menjelaskan mengenai pemilihan atribut mana saja yang nantinya akan menjadi kunci jawaban yang akan tampil pada saat metodenya dijalankan

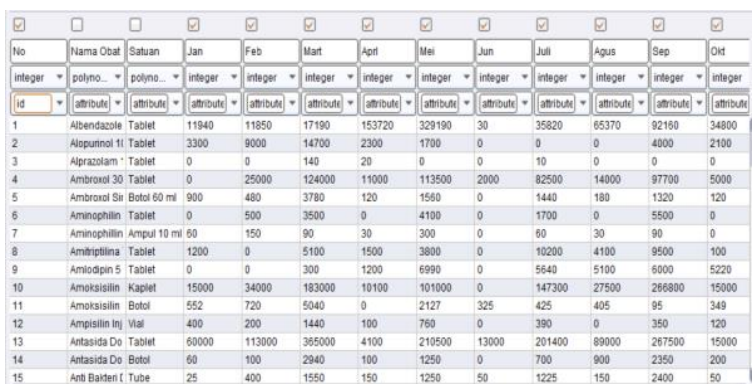

Gambar 3. Proses pemilihan atribut

\section{Proses pemilihan algoritma}

Kemudian pada tahap ini menjelaskan proses pemilihan Operator View penginputan dataset, akan tetapi tidak hanya itu pada gambar 4 ini juga menunjukkan proses pemilihan algoritma yang akan digunakan dalam mengolah dataset yang akan dijadikan sebagai hasil atau informasi yang diinginkan oleh peneliti baik itu berupa Text View dan lainnya jika proses output Read View telah selesai dilakukan.

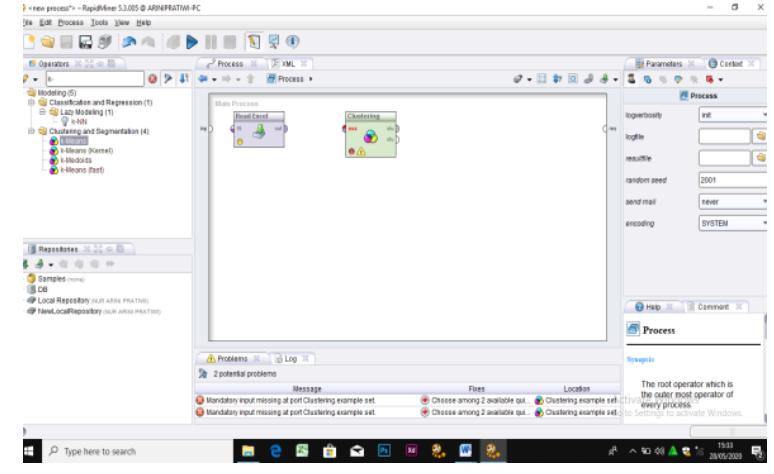

Gambar 4. Proses Pemilihan Algoritma

5. Relasi Antar Operator

Selanjutnya pada tahapan diabawah ini menjelaskan hubungan/relasi antar operator 
untuk selanjutnya dapat dijalankan dan mendapatkan hasil yang diinginkan, namun kita juga harus melihat apakah ada kesalahan atau tidak, jika terjadi kesalahan maka akan ada tanda seru pada operator View, dan apabila berwarna hijau disemua operator view tersebut maka aplikasi dapat dijalankan untuk bisa melihat hasilnya.

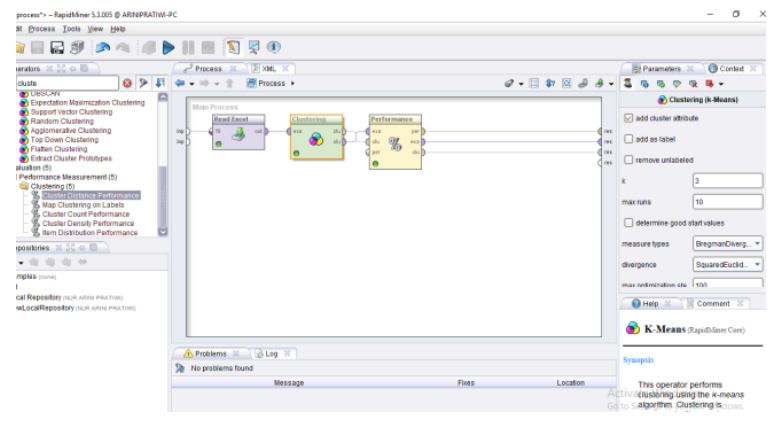

Gambar 5. Proses Relasi Antar Operator

\section{Tampilan data view}

Kemudian dibawah ini menjelaskan tampilan dari dataset setelah aplikasi dijalankan dimana kunci jawaban yang telah ditentukan. Maka terlihat jelas pembagian kelompok anggotanya dari cluster 0 , cluster 1 , dan cluster 2 .

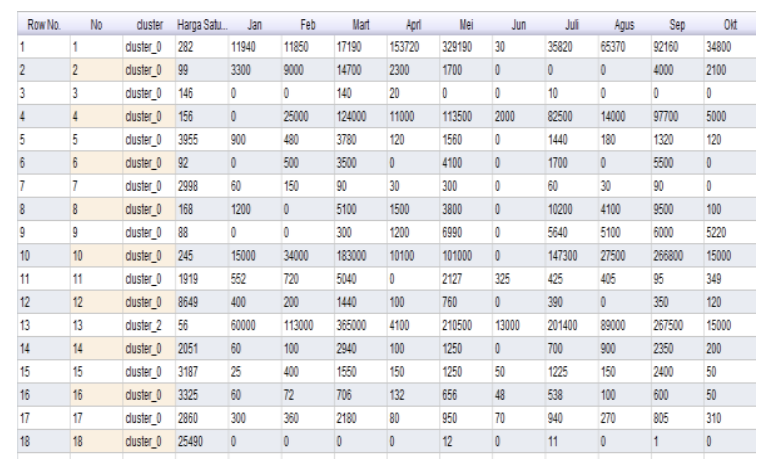

Gambar 6. Tampilan Data View.

\section{Centroid}

Centroid adalah titik atau tolak ukur dalam menentukan anggota kelompok, karena proses clustering ini merupakan suatu proses menentukan pembentukan kelompok berdasarkan jarak dari masing-masing dataset.[16]

\begin{tabular}{|l|l|l|l|}
\hline \multicolumn{1}{|c|}{ Attribute } & \multicolumn{1}{c|}{ cluster_o } & \multicolumn{1}{c|}{ cluster_1 } & \multicolumn{1}{c|}{ cluster_2 } \\
\hline Harga Satua & 16998.832 & 920685.625 & 161.333 \\
\hline Jan & 3170.394 & 2.250 & 131200 \\
\hline Feb & 6977.927 & 1.500 & 103243.333 \\
\hline Mart & 14244.155 & 11.750 & 390646.667 \\
\hline Aprl & 7139.959 & 2.250 & 60196.667 \\
\hline Mei & 15175.207 & 10 & 466923.333 \\
\hline Jun & 2265.917 & 0.250 & 105253.333 \\
\hline Juli & 10581.938 & 3 & 607780 \\
\hline Agus & 4408.948 & 1.250 & 154550 \\
\hline Sep & 14953.280 & 4.250 & 293270 \\
\hline Okt & 2226.907 & 1.750 & 70450 \\
\hline Nov & 13006.528 & 5.500 & 375516.667 \\
\hline Des & 1335.549 & 0.750 & 28930 \\
\hline & & & \\
\hline
\end{tabular}

Gambar 7. Tampilan Centroid Tabel

8. Cluster Model (Clustering)

Cluster model ini merupakan inti dari hasil proses clustering, dimana hasil ini masih alam bentuk model yang umum yang artinya belum dijelaskan secara detail mengenai hasil clustering itu sendiri. Berikut ini merupakan tampilan cluster model yang dihasilkan setelah RapidMiner5 dijalankan.

\section{Cluster Model \\ Cluster 0: 193 items \\ Cluster 1: 4 items \\ Cluster 2: 3 items \\ Total number of items: 200}

Gambar 8 cluster model 


\section{Kesimpulan}

Berdasarkan penelitian yang telah dilakukan maka dapat ditarik kesimpulan sebagai berikut :

- Kriteria obat yang paling banyak di dinas kesehatan kabupaten lombok timur adalah sebanyak 193 item. Hal ini disebabkan karena pemakainnya paling banyak dilihat dari pemakaian perbulan.

- Kelompok obat yang pemakaiannya lebih sedikit ada 2 irisan yaitu pertama obat dengan jumlah kelompok 4 item yang pemakaiannya lebih sedikit dari kelompok 1. Kedua yaitu obat dengan jumlah kelompok 3 item yang pemakaiannya paling sedikit dari kelompok 1 dan kelomok 2.

\section{Daftar Pustaka}

[1] M. H. Adiya and Y. Desnelita, "Jurnal Nasional Teknologi dan Sistem Informasi Penerapan Algoritma K-Means Untuk Clustering Data Obat-Obatan Pada RSUD Pekanbaru," vol. 1, pp. 17-24, 2019.

[2] M. A. Amri, D. Hartama, A. P. Windarto, G. F. K-means, and A. D. A. N. Pembahasan, "Penerapan Data Mining Pada Presentasi Penerimaan Imunisasi Anak-Anak Menurut Provinsi Menggunakan K-Means Clustering," 2020.

[3] T. Anjarsari and A. Putra, "Pengelompokan Penyebaran Penyakit Ispa Di Wilayah Kota Sekayu Menggunakan Algoritma K-Means Clustering ( Studi Kasus : Rsud Sekayu )," pp. 174-184, 2019.

[4] A. S. Dzihni, R. Andreswari, and M. A. Hasibuan, "ScienceDirect ScienceDirect Business Process Analysis and Academic Information System Audit of Helpdesk Application using Genetic Algorithms a Process Mining Approach," Procedia Comput. Sci., vol. 161, pp. 903-909, 2019.

[5] C. Astria, A. P. Windarto, A. Wanto, and E. Irawan, "Metode K-Means Pada
Pengelompokan Wilayah Pendistribusian Listrik," pp. 306-312, 2019.

[6] D. N. Batubara, A. P. Windarto, D. Hartama, and $H$. Satria, "Analisis Metode K-MEANS Pada Pengelompokan Keberadaan Area Resapan Air Menurut Provinsi," no. x, pp. 345-349, 2019.

[7] M. Anjelita, A. P. Windarto, and A. Wanto, "Analisis Metode K-Means pada Kasus Ekspor Barang Perhiasan dan Barang Berharga Berdasarkan Negara Tujuan," pp. 476-482, 2019.

[8] D. Novianti and N. Palasara, "Novianti, Klasterisasi Negara Pendaftar Paten Di Indonesia Menggunakan K-Means 446," vol. 8, no. September, pp. 446-457, 2019.

[9] V. Game, "Penerapan Algoritma K-Means Clustering pada Karakter Permainan Multiplayer Online Battle Arena," vol. 6, no. 2, pp. 246-254, 2021.

[10] A. M. Hemeida, S. Alkhalaf, A. Mady, E. A. Mahmoud, M. E. Hussein, and A. M. Baha, "Implementation of nature-inspired optimization algorithms in some data mining tasks," Ain Shams Eng. J., vol. 11, no. 2, pp. 309-318, 2020.

[11] I. P. E.- Issn, "Computer Based Information System Journal Analisis Clustering Menggunakan Algoritma K-MeanS Mesri Silalahi," vol. 2, pp. 20-35, 2018.

[12] M. G. Sadewo et al., "PENERAPAN ALGORITMA CLUSTERING," vol. 2, pp. 311-319, 2018.

[13] I. W. S. Wicaksana, "Data Mining Dengan Rapid Miner," p. 8, 2015.

[14] R. Setiawan and N. Tes, "Penerapan Data Mining Menggunakan Algoritma K-Means Clustering Untuk Menentukan Strategi Promosi Mahasiswa Baru ( Studi Kasus: Politeknik LP3I Jakarta )," vol. 3, no. 1, pp. 76-92, 2016.

[15] W. Gunawan et al., "ScienceDirect ScienceDirect Named-Entity Recognition for Indonesian Language using Named-Entity Recognition for Indonesian Language using Bidirectional LSTM-CNNs Bidirectional LSTM-CNNs," Procedia Comput. Sci., vol. 135, pp. 425-432, 2018.

[16] F. Sun, B. Yan, and D. Xin, "Biomedicine \& Pharmacotherapy Data mining and 
Infotek : Jurnal Informatika dan Teknologi

Vol. 3 No. 2, Juli 2020, hal. 147-156

systematic pharmacology to reveal the mechanisms of traditional Chinese medicine in Mycoplasma pneumoniae pneumonia treatment," Biomed. Pharmacother., vol. 125, no. December 2019, p. 109900, 2020. 